\title{
Role of conceptus secretory products in establishment of pregnancy
}

\author{
F. W. Bazer*, J. L. Vallet*. R. M. Roberts $\dagger$, D. C. Sharp* and \\ W. W. Thatcher $\ddagger$ \\ *Animal Science Department and $\ddagger$ Dairy Science Department in Institute of Food and Agricultural \\ Sciences and + Department of Biochemistry and Molecular Biology, College of Medicine, \\ University of Florida, Gainesville, FL 32611, U.S.A.
}

\begin{abstract}
Summary. Conceptuses produce steroids, prostaglandins, proteins and possibly other unidentified agents which may play a role in the establishment and maintenance of pregnancy. A key event in this process is protection of the corpus luteum (CL) from the luteolytic activity of prostaglandin (PG) F-2 $\alpha$ of uterine origin. Oestrogens produced by the pig conceptuses between Days 11 and 16 appear to exert an antiluteolytic effect resulting in the sequestering of PGF- $2 \alpha$ within the uterine lumen. Failure of the pregnant uterus to release PGF- $2 \alpha$ in an endocrine fashion, therefore, allows for maintenance of CL function. Conceptuses of sheep and cattle produce proteins which, when introduced into the uterine lumen of nonpregnant ewes and cows, suppress the ability of oestradiol and oxytocin to stimulate uterine production of PGF-2 $\alpha$. These conceptus secretory proteins appear to exert an antiluteolytic effect by inhibiting uterine production of luteolytic amounts of PGF-2 $\alpha$. The horse conceptus produces both oestrogens and proteins during early pregnancy when uterine production of PGF-2 $\alpha$ is suppressed. Co-culture of horse endometrium and conceptus inhibits endometrial production of PGF-2 $\alpha$. Conceptuses of pigs, sheep and cattle undergo elongation to achieve apposition between trophectoderm and endometrium but the horse embryo migrates rapidly and consistently throughout the uterus to achieve endometrial contact.
\end{abstract}

\section{Introduction}

Conceptuses of domestic animals produce proteins, steroids and prostaglandins during early pregnancy which may be involved in protecting the corpora lutea (CL) from the luteolytic effects of prostaglandin (PG)F-2 $\alpha$ produced by the uterine endometrium. Agents such as these may function as antiluteolysins or luteotrophins. However, available data strongly suggest that conceptuses of domestic farm animals produce antiluteolytic agents. Conceptus secretory products also act to allow survival of the conceptus allograft, stimulate vasodilatation and angiogenesis to increase uterine blood flow and substrate delivery to the pregnant uterus, stimulate active transport of nutrients into the uterine lumen from maternal tissues and fluids, regulate intrauterine migration of embryos and placentation as well as other events associated with establishment and maintenance of pregnancy. This review will focus only on current concepts of how the conceptus acts to protect the CL and allow for its continued production of progesterone. Progesterone is essential for maintenance of a uterine environment supportive of conceptus development. In particular, progesterone-induced endometrial development and secretion of endometrial histotroph appears essential for nourishment of conceptuses having fusion-type implantation (Schlafke \& Enders, 1975), e.g. pigs, sheep, cattle and horses. 


\section{Pig}

The theory of maternal recognition of pregnancy in the pig (Bazer \& Thatcher, 1977) has been reviewed extensively (see Bazer, Geisert, Thatcher \& Roberts, 1982; Bazer, Marengo, Geisert \& Thatcher, 1984). Therefore, only a few key points will be reviewed here.

The pig blastocyst expands from about 0.5 to $1 \mathrm{~mm}$ diameter at hatching to $2-6 \mathrm{~mm}$ on Day 10 before elongating rapidly to a filamentous form of $700-1000 \mathrm{~mm}$ length by 0.5 to $1.0 \mathrm{~mm}$ diameter between Days 11 and 14 to 16 of pregnancy (see Bazer \& First, 1983). Pig blastocysts begin to produce oestrogens at the $10 \mathrm{~mm}$ spherical stage and increase amounts produced to about Day 12 when oestrogen production decreases between Days 13 and 14 before increasing again between Days 15 and 25-30 of gestation (Gadsby, Heap \& Burton, 1980; Stoner, Geisert, Bazer \& Thatcher, 1981; Fischer, Bazer \& Fields, 1985). Available data indicate that oestrogens produced by pig conceptuses provide the signal for establishment of pregnancy. Pseudopregnancy, prolonged maintenance of $\mathrm{CL}$ in pigs, can be induced by daily injections of oestradiol valerate between Days 11 and 15 after onset of oestrus (Day 0). As noted previously, production of oestrogens by pig conceptuses is biphasic with increased production on Days 11-12 and 15 to 25-30. To induce pseudopregnancy successfully, Geisert, Biggers, Wettemann \& Zavy (1984) reported that a single injection of oestradiol benzoate on Day 11 will allow CL maintenance to only Day 30 after oestrus. Injections on Day 11 and Days 14-16 are required if pseudopregnancy is to persist for more than 60 days. Data relative to oestrogen production by pig conceptuses and the effect of oestrogen injections on maintenance of $\mathrm{CL}$ in nonpregnant pigs strongly suggest that the oestrogens act directly or indirectly to allow for maintenance of CL by exerting an antiluteolytic effect.

Concentrations of PGF-2 $\alpha$ in utero-ovarian vein plasma and the 15-keto-13,14-dihydroPGF- $2 \alpha$ metabolite of PGF-2 $\alpha$ (PGFM) in peripheral plasma are elevated during the period of luteolysis in nonpregnant pigs, but they are not elevated between Days 12 and 25 of pregnancy (see Bazer et al., 1984). These data suggested that luteolysis was temporally associated with the period of increased uterine production of PGF and that uterine production of PGF was either inhibited during pregnancy or PGF secretion into the uterine venous drainage was inhibited. When PGF was measured in uterine flushings of pregnant and pseudopregnant gilts it was present in significantly greater amounts than that measured in uterine flushings from cyclic gilts. Total recoverable PGF in uterine flushings from Day 19 of pseudopregnancy was about $10226 \mathrm{ng}$ compared to $210 \mathrm{ng}$ for appropriate controls. Total recoverable PGF in uterine flushings was greater for pregnant than nonpregnant gilts on Days 12 (144 vs $36 \mathrm{ng}$ ) and 18 (22 688 vs $680 \mathrm{ng}$ ). Lewis \& Waterman (1982) reported PGF production by pig blastocysts which may account for higher PGF in uterine flushings of pregnant than nonpregnant gilts. It is also possible that oestrogens produced by the conceptus stimulate endometrial PGF production (Poyser, 1984). These data indicated that: (1) neither conceptus secretions in general nor oestrogens in particular were inhibiting uterine production of PGF; (2) the uteri of pregnant and pseudopregnant gilts were able to sequester substantial amounts of PGF; and (3) the conceptus contributes to PGF measured in uterine flushings from pregnant gilts.

Collectively, available data suggest that the pig endometrium plays an endocrine role during the oestrous cycle. That is, the endometrium produces PGF, which is released primarily into the uterine venous drainage for transport to the $\mathrm{CL}$ where it induces luteolysis to ensure that the oestrous cycles are recurring until pregnancy is established. In the pregnant pig, evidence of increased endocrine secretion of PGF is not detected as PGFM in the utero-ovarian vein or peripheral plasma. In fact, recoverable PGF in uterine flushings is substantially increased due to secretion of PGF in an exocrine direction, i.e. into the uterine lumen, where PGF of uterine and conceptus origin is sequestered. Unlike the ewe (Fincher, Hansen, Thatcher, Roberts \& Bazer, 1984) and cow (Knickerbocker et al., 1984), which have elevated basal concentrations of PGFM in peripheral plasma due probably to conceptus production of PGF, basal concentrations of PGFM in peripheral plasma are not elevated in pregnant pigs (Terqui, Martinat-Botte \& Thatcher, 1979). As 
part of the exocrine secretion or histotroph of pig endometrial secretions, prostaglandins may exert an array of effects critical to the establishment and maintenance of pregnancy. These include effects on uterine blood flow, vascular permeability, fluid and electrolyte transport, cellular proliferation, steroid biosynthesis and immunoprotection of the conceptus (see Bazer et al., 1982).

The endocrine-exocrine theory for establishment of pregnancy in pigs remains incomplete because the mechanism whereby oestrogens affect transport of PGF from the uterine lumen is not known. The oestrogens may act directly or they may affect other hormones which act on the uterine endometrium or CL. Data are not available to indicate that pig conceptuses produce a luteotrophin. Pig conceptuses do secrete two major classes of proteins $\left(M_{\mathrm{r}} \cong 20000-25000\right.$, $\mathrm{pI} \cong 5 \cdot 6-6 \cdot 2$, and $M_{\mathrm{r}} \cong 35000$ to $50000, \mathrm{pI} \cong 8.0$ ) between Days 10.5 and $16-18$, but their role(s) has not been established (Godkin, Bazer, Lewis, Geisert \& Roberts, 1982). Although CL maintenance can be extended by injecting horse chorionic gonadotrophin on Day 14 (Hunter, 1964) or human chorionic gonadotrophin on Day 12 (Guthrie \& Rexroad, 1981), a pig chorionic gonadotrophin has not been identified. Infusion of prostaglandins of the E series into the uterine lumen has also been without effect on CL maintenance (see Bazer et al., 1982). However, Ball \& Day (1982) and Chakraborty, England \& Stormshak (1972) suggested direct effects of steroids on corpora lutea. Garverick, Polge \& Flint (1982), for example, reported that oestradiol increased unoccupied LH receptors in CL of intact and hysterectomized pigs.

Luteotrophic or luteostatic agents produced by the pig conceptus appear unlikely for at least two reasons. First, CL maintenance is readily achieved by hysterectomizing pigs and removing the PGF source so long as basal LH support is available. Second, luteotrophic or luteostatic agents such as oestrogens or a polypeptide would be expected to have a systemic effect. However, at least two conceptuses must be present in each uterine horn of pigs for establishment of pregnancy and CL maintenance.

\section{Sheep}

Sheep blastocysts are spherical between Days 4 and $10(0.14$ to $0.4 \mathrm{~mm}$ diameter $)$ and then elongate to the filamentous form by Day 15 (150-190 mm by 1-2 mm). Moor \& Rowson (1966a, b) initially reported that intrauterine, but not intravenous, infusion of homogenates of Day 14-15 ovine conceptuses extended CL life-span. Martal, Lacroix, Loudes, Saunier \& Wintenberger-Torres (1979) suggested that a protein which they called 'trophoblastin' was responsible for extending CL life-span when infused into the uterine lumen. Neither luteinizing hormone $(\mathrm{LH})$ nor prolactin-like activity has been detected in sheep conceptus homogenates (Ellinwood, Nett \& Niswender, 1979) or secretory products (Martal et al., 1979).

We raised the question of whether or not sheep conceptuses produce proteins that might be considered to have antiluteolytic or luteotrophic properties. The question was examined using techniques developed by Basha, Bazer \& Roberts (1979) to study radiolabelled proteins secreted by endometrial explant cultures. Day 16 sheep conceptuses were initially cultured in the presence of $\left[{ }^{14} \mathrm{C}\right]$ leucine, $\left[{ }^{35} \mathrm{~S}\right]$ methionine and $\left[{ }^{3} \mathrm{H}\right]$ glucosamine for $30 \mathrm{~h}$ and incorporation of radiolabels into macromolecules secreted into the medium was linear for $\left[{ }^{3} \mathrm{H}\right]$ glucosamine and $\left[{ }^{14} \mathrm{C}\right]$ leucine and quadratic for $\left[{ }^{35} \mathrm{~S}\right]$ methionine. Analysis of culture medium by two-dimensional-PAGE indicated that the major radiolabelled proteins were three closely related isoelectric species with molecular weights initially estimated at $25000 \pm 2000$ by two-dimensional-PAGE and about 20000 by Sephadex G200 gel filtration chromatography (Wilson, Lewis \& Bazer, 1979). Godkin, Bazer, Moffatt, Sessions \& Roberts (1982) later demonstrated that those proteins had molecular weights of 17000 and pIs of 5.3-5.7 and named them ovine trophoblast protein 1. They are produced between Days 12 and 21 of gestation. Available data indicate that ovine trophoblast protein 1 is: (1) produced by trophoblast; (2) taken up by surface and upper uterine gland epithelium; (3) without lactogenic activity; (4) without stimulatory effects on progesterone production by luteal slices or 
dispersed luteal cells although there was specific binding to luteal cell membranes with high affinity; and (5) stimulatory to protein secretion by ovine endometrial explant cultures from Day 12 cyclic ewes. However, there is no evidence that the protein is transported from the uterus into the maternal circulation (Godkin, Bazer \& Roberts, 1984a); therefore, it is assumed to have an antiluteolytic role.

Experiments (Godkin, Bazer, Thatcher \& Roberts, 1984b) were next conducted to determine effects of purified ovine trophoblast protein 1 and total Day- 16 conceptus secretory proteins on luteal life-span when introduced into the uterine lumen of non-pregnant ewes. Introduction of $2 \mathrm{mg}$ per day of Day- 16 conceptus secretory proteins from Days 12 to 18 into the uterine lumen of 3 nonpregnant ewes increased the interoestrous intervals to 24,34 , and $>52$ days. Infusion of $200 \mu \mathrm{g}$ ovine trophoblast protein 1 daily from Days 12 to 20 extended CL life-span by only 4-5 days. That ovine trophoblast protein 1 was not as effective as conceptus secretory protein may be due to: (1) infusion of inadequate amounts of the trophoblast protein; (2) its partial degradation during purification or in utero; or (3) trophoblast protein 1 may be only one component of an antiluteolytic complex secreted by the conceptus.

Since conceptus secretory proteins infused into the uterine lumen extended CL life-span, an antiluteolytic role was considered. McCracken, Schramm \& Okulicz (1984) proposed that uterine production of PGF is regulated by oestradiol which induces oxytocin receptors and that oxytocin binding to these receptors stimulates phospholipase $\mathrm{A}_{2}$, the arachidonic acid cascade and production of luteolytic amounts of PGF. Kittok \& Britt (1977) reported that doses of oestradiol which caused luteolysis in nonpregnant ewes were only partly effective in inducing luteolysis in pregnant ewes. Also, Fairclough, Moore, Peterson \& Watkins (1984) found significantly less PGF production induced by oxytocin in pregnant compared with non-pregnant ewes. In addition, Zarco, Stabenfeldt, Kindahl, Bradford \& Basu (1984) detected a mean of 5.5 pulses or episodes of PGF production per $25 \mathrm{~h}$ in non-pregnant ewes compared to only $1.3 / 25 \mathrm{~h}$ for pregnant ewes. Therefore, we (Fincher et al., 1984) conducted two studies to determine whether: (1) uterine PGF production in response to oestradiol was inhibited in pregnant ewes and (2) conceptus secretory proteins inhibit oestradiol and oxytocin-induced uterine production of PGF. In both experiments, uterine production of PGF was measured indirectly as PGFM in jugular venous plasma.

In the first experiment $0.5 \mathrm{mg}$ oestradiol- $17 \beta$ in $1 \mathrm{ml} 0.9 \%(\mathrm{w} / \mathrm{v}) \mathrm{NaCl}$-ethanol vehicle or vehicle only was injected i.v. into the jugular vein of pregnant and non-pregnant ewes on Day 14 after onset of oestrus. Jugular vein blood samples were collected at 30 and 1 min before treatment and at 30-min intervals for $10 \mathrm{~h}$ after treatment. Plasma was obtained from each sample and assayed for PGFM. Before treatment with oestradiol basal PGFM concentrations (mean \pm s.e.m.) were higher $(P<0.01)$ for pregnant than non-pregnant ewes $(193 \pm 30 v s 67 \pm 8 \mathrm{pg} / \mathrm{ml})$. Between . 4 and $10 \mathrm{~h}$ after oestradiol, non-pregnant ewes responded with distinct episodes of increased PGFM $(50-1556 \mathrm{pg} / \mathrm{ml})$ which were not detected in pregnant ewes $(50-533 \mathrm{pg} / \mathrm{ml})$.

In the second experiment, conceptus secretory proteins (oCSP) were injected into the uterine lumen at 08:00 and 17:00 h (750 $\mu \mathrm{g} \mathrm{oCSP}+750 \mu \mathrm{g}$ serum protein) on Days 12-14. Control ewes received intrauterine injections of $1500 \mu \mathrm{g}$ serum protein at the same times. All ewes were injected with oestradiol-17 $\beta$ on Day 14, as in the previous experiment, and with $10 \mathrm{i} . \mathrm{u}$. oxytocin at $08: 05 \mathrm{~h}$ on Day 15. Mean uterine production of PGF, measured as PGFM, was lower $(P<0.05)$ for oCSPtreated ewes $(371 \pm 129$ vs $1188 \pm 139 \mathrm{pg} / \mathrm{ml})$ after oestradiol treatment and after oxytocin treatment $(1669 \pm 287$ vs $3972 \pm 2199 \mathrm{pg} / \mathrm{ml})$. Data from this experiment indicate that conceptus secretory proteins inhibit the ability of oestradiol-17 $\beta$ and oxytocin to induce uterine production of PGF and are compatible with results from experiments with pregnant ewes (Kittok \& Britt, 1977; Fairclough et al., 1984). It is not known whether endometrial proteins induced by conceptus secretory proteins or trophoblast protein 1 inhibit PGF production. However, purified trophoblast protein 1 does not compete with oxytocin in an endometrial membrane oxytocin receptor assay (A. P. F. Flint, J. L. Vallet, F. W. Bazer \& R. M. Roberts, unpublished data).

As noted previously, Godkin et al. (1984a) reported that ovine trophoblast protein 1 stimulates 
secretion of certain proteins by endometrium from non-pregnant ewes. These results have been confirmed (Vallet, Bazer \& Roberts, 1985a) and extended to indicate that the stimulatory effect of trophoblast protein 1 on secretion of certain endometrial proteins is also antagonized by cAMP $(r=-0.72, P<0.1)$. In another experiment ovine trophoblast protein 1 decreased cAMP ( $\mathrm{pmol} / \mathrm{mg}$ endometrium) when compared to bovine serum albumin in endometrial culture medium $(0.41$ vs $0 \cdot 29, P<0 \cdot 1)$. Effects of endometrial proteins induced by trophoblast protein 1 on progesterone production by slices of luteal tissue from Day 12 of the cycle were not significant (Vallet, Bazer \& Roberts, 1985b). Available data suggest that progesterone production by CL is not stimulated by ovine trophoblast proteins 1 or endometrial proteins induced by them.

Silvia, Ottobre \& Inskeep (1984) reported that PGE-2 in utero-ovarian vein plasma of ewes increases dramatically on Days 13 and 14 of pregnancy. It is possible that trophoblast protein 1 and/or other conceptus secretory proteins alter enzymic conversion of intermediates in prostaglandin biosynthesis to favour a high PGE-2:PGF-2 $\alpha$ ratio which may favour luteal maintenance. It seems unlikely that conceptus secretory proteins affect PGF production by affecting oestradiol receptors since numerous oestradiol-mediated effects are required for establishment and maintenance of pregnancy. Likewise, conceptus secretory proteins may not alter mechanisms responsible for tonic secretion of PGF by conceptus and endometrial tissues since basal PGFM concentrations are higher in pregnant than non-pregnant ewes. However, conceptus secretory proteins may affect oxytocin and/or other agents responsible for episodic release of PGF which McCracken et al. (1984) and Zarco et al. (1984) suggest as being essential for luteolysis.

\section{Cow}

Blastocysts of cows are spherical $(0.2 \mathrm{~mm}$ diameter) on Days $8-9$, tubular $(1.5-3.3 \mathrm{~mm}$ by $0.9-1.7 \mathrm{~mm})$ on Days 12-13 and then become filamentous between Days 13-14 (1.5 $\times 1.0 \mathrm{~mm})$ and $17-18(1.5 \times 160 \mathrm{~mm})$, and by Day 24 the conceptus occupies both uterine horns (see Bazer \& First, 1983). During this period of elongation, cow conceptuses produce limited quantities of progesterone, androstenedione and oestradiol (Shemesh, Milaguir, Ayalon \& Hansel, 1979; Eley, Thatcher, Bazer \& Fields, 1983) as well as $5 \beta$-reduced androgens and progestagens (Thatcher et al., 1985). However, the role of these steroids in early pregnancy is not known.

The cow conceptus allows for maintenance of $\mathrm{CL}$ function and signals its presence by Days 16-17 (Betteridge, Eaglesome, Randall \& Mitchell, 1980). Cows from which conceptuses were removed on Days 17 and 19 had interoestrous intervals of $25 \pm 1$ and $26 \pm 1$ days compared to $20 \pm 1$ days when conceptuses were removed on Day 13 (Northey \& French, 1980). Also, transfer of embryos to recipient cows on Day 16, but not Day 17, resulted in normal pregnancies (Betteridge et al., 1980). Furthermore, twice daily intrauterine injections of Day 17-18 conceptuses (Northey \& French, 1980) or freeze-killed Day 16 conceptuses (Dalla Porta \& Humboldt, 1983) on Days 14-18 or 15-19 extended CL function for 4-8 days, but injection of Day 12 conceptuses was without effect on CL life-span.

Thatcher et al. (1985) have reviewed events and mechanisms related to establishment of pregnancy in the cow; therefore, the reader is referred to that reference for detail additional to that presented in this review. Thatcher et al. (1985) provide evidence that PGF is the uterine luteolysin and that oestradiol stimulates uterine production of PGF and, therefore, has a luteolytic effect in cyclic cows. Oxytocin is also luteolytic in cows and stimulates uterine production of PGF (Lafrance \& Goff, 1985). Oestradiol-induced PGF production by the uterus is inhibited by the presence of the conceptus and this inhibition is greater at Day 20 than Day 18 as the conceptus achieves more extensive contact with the uterine endometrium (see Thatcher et al., 1985). Likewise, Lafrance \& Goff (1985) reported that the bovine conceptus inhibits uterine production of PGF in response to oxytocin.

Bovine conceptuses cultured in the presence of $\left[{ }^{3} \mathrm{H}\right]$ leucine, as described earlier for sheep 
conceptuses, secrete several radiolabelled polypeptides into the medium. The major proteins secreted between Days 16 and 24-27 have molecular weights of 22000 to 26000 and pIs of 5.6-6.8 (Bartol et al., 1984). These proteins are hereafter referred to as bovine trophoblast protein 1. Antiserum to ovine trophoblast protein 1 cross-reacts with two components of bovine trophoblast protein 1 . These results indicate at least partial homology between low molecular weight acidic proteins produced by sheep and cattle conceptuses during the period of establishment of pregnancy (S. Helmer, P. J. Hansen, W. W. Thatcher, R. M. Roberts \& F. W. Bazer, unpublished data). Luteal maintenance in recipient cows and ewes after interspecies transfer of trophoblastic vesicles argues further for similar mechanisms leading to establishment of pregnancy in ewes and cows (Heyman, Camous, Fevre, Meziou \& Martal, 1984).

Two experiments have been conducted using bovine conceptus secretory proteins obtained from medium in which Day 16-18 conceptuses were cultured for about $30 \mathrm{~h}$ (see Thatcher et al., 1985). In the first experiment, $740 \mu \mathrm{g}$ conceptus secretory proteins were injected into the uterine lumen of cyclic Holstein cows at 20:00 h on Day 15 and 08:00 and 20:00 h on Days 16-21. Cows receiving bCSP had longer $(P<0.01)$ interoestrous intervals $(30-39$ days) than those receiving serum proteins (23-24 days). Cows receiving conceptus secretory proteins also had lower $(P<0.01)$ concentrations of PGF in inferior vena cava plasma. In the second experiment, 10 cyclic Jersey cows received intrauterine injections of $600 \mu \mathrm{g}$ conceptus secretory proteins or $600 \mu \mathrm{g} \mathrm{serum}$ protein at 20:00 h on Day 15, 08:00 and 20:00 h on Days 16-17 and 08:00 h on Day 18. From 07:00 h on Day 18 blood samples were obtained at 30-min intervals for $12 \mathrm{~h}$ and assayed for concentrations of PGFM in plasma. Each cow received $3 \mathrm{mg}$ oestradiol at $08: 00 \mathrm{~h}$ to stimulate uterine production of PGF. Overall mean for PGFM was lower $(P<0.01)$ for cows receiving conceptus secretory proteins after oestradiol $(74 \pm 5$ vs $171 \pm 14 \mathrm{pg} / \mathrm{ml})$. Available evidence suggests that cows, like ewes, receiving intrauterine injections of conceptus secretory proteins do not increase uterine PGF production in response to oestradiol.

Luteal regression in cyclic cows is associated with 3-5 episodes of PGFM in plasma which are markedly reduced or absent in pregnant cows (see Thatcher et al., 1985). Similar differences were noted earlier for pregnant and non-pregnant ewes. Luteal oxytocin has also been reported for the ewe (Flint \& Sheldrick, 1983) and cow (Wathes, Swann \& Pickering, 1984) and is believed to be involved in luteolysis. Further research is needed to determine how bovine trophoblast protein 1 and/or conceptus secretory proteins inhibit uterine production of PGF in response to oestradiol and oxytocin. However, data are available to indicate that endometrial production of PGF is reduced in pregnant cows although basal values of PGFM are higher for pregnant cows, as they are for pregnant ewes (see Thatcher et al., 1985).

\section{Mare}

Horse conceptuses do not undergo rapid elongation, but expand rapidly as spherical organisms between Days 8 and 20 of gestation. Intrauterine migration of the horse conceptus is extensive (Ginther, 1983) and this may allow its secretions to affect the entire endometrium and allow for establishment of pregnancy. McDowell, Sharp, Peck \& Cheves (1985) reported that restriction of the horse conceptus to one uterine horn resulted in luteal regression and presumably loss of uterine histotroph before death and resorption of the conceptus. To demonstrate that the endometrium to which the conceptus has no access was causing luteolysis before conceptus death, they confirmed that 1 of 8 mares remained pregnant when the conceptus was restricted to one uterine horn. However, 5 of 7 unilaterally pregnant mares maintained their pregnancies until 32 days (one mare) and more than 42 days ( 4 mares) when fed a synthetic progestagen, altrenogest (allyl trenbolone), at $2.2 \mathrm{mg}$ per $50 \mathrm{~kg}$ body weight daily from Day 8 or 9 after ovulation. These data indicate that luteolysis occurs in unilaterally pregnant mares and, in the absence of progestational support, endometrial function is compromised and death of the conceptus ensues. 
Sharp et al. (1984) recently reviewed the role of PGF as the uterine luteolytic agent in cyclic mares and effects of pregnancy on uterine production of PGF. Generally, they indicated that endometrial production, uterine fluid content and uterine venous plasma concentrations of PGF are elevated in cyclic mares during luteolysis, Days 14-16, but PGF concentrations are lower in uterine fluid and uterine venous plasma during pregnancy. Paradoxically, endometrium from pregnant mares cultured in vitro produced a substantial quantity of PGF, but co-culture of pregnant endometrium with conceptus membranes reduced PGF production. This suggests that the effect of the conceptus on PGF production is relatively transient (Sharp et al., 1984). Administration of oestradiol to ovariectomized mares after progesterone treatment for 14 days resulted in highest rates of endometrial production of PGF. As discussed previously for the ewe and cow, oxytocin also stimulates uterine PGF production after Day 11 of the cycle by more than 30 -fold (Goff $\&$ Pontriand, 1985).

Kooistra \& Ginther (1976) demonstrated that removal of the equine conceptus on Day 24 resulted in an extended interoestrous interval of $34.8 \pm 5.8$ days. This period of prolonged CL maintenance of 50-60 days was shorter than that for hysterectomized (70-140 days) and pregnant (140-210 days) mares, but suggests that the horse conceptus protects the CL from the uterine luteolysin. Available data suggest that the horse conceptus exerts an antiluteolytic effect to allow maintenance of CL function and establishment of pregnancy. The horse conceptus produces substantial quantities of oestrogens (Zavy, Mayer, Vernon, Bazer \& Sharp, 1979) between Days 8 and 20 of pregnancy. Nishikawa (1959) and Berg \& Ginther (1978) reported prolonged CL maintenance for mares treated with various oestrogens during dioestrus. However, others have not been able to demonstrate an antiluteolytic effect of oestrogen in mares (see Sharp et al., 1984).

Zavy, Vernon, Asquith, Bazer \& Sharp (1984) first reported that uterine luminal PGF was lower in pregnant pony mares and suggested that the horse conceptus may suppress uterine production of PGF. This has been confirmed by Berglund, Sharp, Vernon \& Thatcher (1982) and Sharp \& McDowell (1985) who reported that coincubation of horse conceptus and endometrium from Days 13-14 of pregnancy resulted in significantly reduced endometrial production of PGF. Another interesting aspect of studies by Berglund et al. (1982) was that a 10-to 12-fold increase in uterine luminal PGF was obtained from non-pregnant mares if flushings were obtained using the transcervical technique compared to flushing the uterus after hysterectomy. However, differences in recoverable PGF due to flushing procedure were not detected for pregnant mares. If the increased PGF in flushings obtained transcervically reflect uterine response to increased oxytocin released due to the Ferguson Reflex, data suggest that a conceptus factor inhibits that response. In support of this, Goff \& Pontriand (1985) reported a 34-fold increase in uterine PGF production by nonpregnant mares in response to oxytocin whereas there was only a 4-fold increase for pregnant mares.

The horse conceptus factor which inhibits uterine production of PGF has not been identified. Fazleabas \& McDowell (1983) reported that Day 12-14 horse conceptuses secrete a unique array of at least 5 proteins with molecular weights ranging from 50000 to 400000 ; however, those proteins were not primary secretory products after Day 15-16. From Day 15-16 to Day 28, proteins of yolk sac origin, i.e. transferrin and $\alpha$-fetoprotein, were dominant. The chorioallantois also produces an array of acidic proteins between Days 15-16 and 28 with the 2 dominant groups having estimated molecular weights of 28000 and $<15000$ and pIs of about 6.4 and less than 4 , respectively.

\section{General}

Although there is considerable evidence that conceptus secretory products have an antiluteolytic role, there are also data suggesting that the conceptus produces a luteotrophic agent(s). The most convincing evidence for a luteotrophin comes from studies of Mapletoft, Del Campo \& Ginther (1975). They anastomosed the main uterine veins from gravid and nongravid uterine horns of 
unilaterally pregnant ewes having one $\mathrm{CL}$ in each ovary and found bilateral CL maintenance. They also found that CL regressed when the uterine vein ipsilateral to the conceptus received blood only from the nongravid uterine horn. There are numerous reports suggesting that PGE-2 is luteotrophic in ewes (see Bazer, Sharp, Thatcher \& Roberts, 1981). Another possible luteotrophin is ovine placental lactogen which is first produced between Days 16 and 17 (see Martal et al., 1979). Evidence for an ovine chorionic gonadotrophin has also been presented (see Martal et al., 1979) and it was detected as early as Day 15 of pregnancy. In contrast, Ellinwood et al. (1979) found no lactogenic or gonadotrophic activity in homogenates of Day 14-15 sheep conceptuses.

Data are not available to suggest that cow, horse and pig conceptuses produce a luteotrophic agent. However, PGE-2 is produced by cow and pig conceptuses and may play a role in luteostasis (see Bazer et al., 1981).

The research reported from the University of Florida has been supported by U.S.D.A. Cooperative Agreement 58-7B30-0-255, N.I.H. Grant HD10436 and the Upjohn Co., Agricultural Division, Kalamazoo, Michigan, U.S.A. We thank Mr Patrick Tolley for typing this manuscript. Florida Agricultural Journal Series No. 6593.

\section{References}

Ball, G.D. \& Day, B.N. (1982) Local effects of PGF ${ }_{2 a}$ and embryonic extracts on luteal function in swine. $J$. Anim. Sci. 54, 150-154.

Bartol, F.F., Roberts, R.M., Bazer, F.W., Lewis, G.S., Godkin, J.D. \& Thatcher, W.W. (1984) Characterization of proteins produced in vitro by periattachment bovine conceptuses. Biol. Reprod. 32, 681-694.

Basha, S.M.M., Bazer, F.W. \& Roberts, R.M. (1979) The secretion of a uterine-specific purple phosphatase by cultured explants of porcine endometrium. Dependency upon the state of pregnancy of the donor animal. Biol. Reprod. 20, 431-441.

Bazer, F.W. \& First, N.L. (1983) Pregnancy and parturition. J. Anim. Sci. 57 (Suppl. 2), 425-460.

Bazer, F.W. \& Thatcher, W.W. (1977) Theory of maternal recognition of pregnancy in swine based on estrogen controlled endocrine versus exocrine secretion of prostaglandin $F_{2 a}$ by the uterine endometrium. Prostaglandins 14, 397-400.

Bazer, F.W., Sharp, D.C., Thatcher, W.W. \& Roberts, R.M. (1981) Comparative approach to mechanisms in the maintenance of early pregnancy. In Reproductive Processes and Contraception, pp. 581-618. Ed. K. W. McKerns. Plenum Press, New York.

Bazer, F.W., Geisert, R.D., Thatcher, W.W. \& Roberts, R.M. (1982) The establishment and maintenance of pregnancy. In Control of Pig Reproduction, pp. 227-252. Eds. D. J. A. Cole \& G. R. Foxcroft. Butterworth Scientific, London.

Bazer, F.W., Marengo, S.R., Geisert, R.D. \& Thatcher, W.W. (1984) Endocrine vs exocrine secretion of PGF $_{2 a}$ in the control of pregnancy in swine. In Prostaglandins in Animal Reproduction $I I$, pp. 115-132. Eds L. E. Edqvist \& H. Kindahl. Elsevier Science Publishers, Amsterdam.

Berg, S.L. \& Ginther, O.J. (1978) Effect of estrogens on uterine tone and life span of the corpus luteum in mares. J. Anim. Sci. 47, 203-208.

Berglund, L.A., Sharp, D.C., Vernon, M.W. \& Thatcher, W.W. (1982) Effect of pregnancy and collection technique on prostaglandin $F$ in the uterine lumen of Pony mares. J. Reprod. Fert., Suppl. 32, 335-341.
Betteridge, K.J., Eaglesome, M.D., Randall, G.C.B. \& Mitchell, D. (1980) Collection, description and transfer of embryos from cattle 10-16 days after oestrus. J. Reprod. Fert. 59, 205-216.

Chakraborty, P.K., England, D.C. \& Stormshak, F. (1972) Effect of $17 \beta$-estradiol on pituitary gonadotropins and luteal function in gilts. J. Anim. Sci. 34, $427-429$.

Dalla Porta, M.A. \& Humboldt, P. (1983) Effect of embryo removal and embryonic extracts or $\mathrm{PGE}_{2}$ infusions on luteal function in the bovine. Theriogenology 19, 122-131.

Eley, R.M., Thatcher, W.W., Bazer, F.W. \& Fields, M.J. (1983) Steroid metabolism by the bovine uterine endometrium and conceptus. Biol. Reprod. 28, 804-816.

Ellinwood, W.E., Nett, T.M. \& Niswender, G.D. (1979) Maintenance of the corpus luteum of early pregnancy in the ewe. I. Luteotrophic properties of embryonic homogenates. Biol. Reprod. 21, 281-288.

Fairclough, R.J., Moore, L.G., Peterson, A.J. \& Watkins, W.B. (1984) Effect of oxytocin on plasma concentrations of 13,14-dihydro-15-keto prostaglandin $F$ and the oxytocin associated neurophysin during the estrous cycle and early pregnancy in the ewe. Biol. Reprod. 31, 36-43.

Fazleabas, A.T. \& McDowell, K.J. (1983) Synthesis and release of polypeptides by horse conceptus tissue and extra-embryonic membranes during early and midgestation. Biol. Reprod. 28 (Suppl. 1), 138, Abstr.

Fincher, K.B., Hansen, P.J., Thatcher, W.W., Roberts, R.M. \& Bazer, F.W. (1984) Ovine conceptus secretory proteins suppress induction of prostaglandin $\mathrm{F}_{2 \mathrm{a}}$ release by estradiol and oxytocin. J. Anim. Sci. 59 (Suppl. 1), 369, Abstr.

Fischer, H.E., Bazer, F.W. \& Fields, M.J. (1985) Steroid metabolism by endometrial and conceptus tissues during early pregnancy and pseudopregnancy in swine. J. Reprod. Fert. 75, 69-78.

Flint, A.P.F. \& Sheldrick, E.L. (1983) Evidence for a systemic role for ovarian oxytocin in luteal regression in sheep. J. Reprod. Fert. 67, 215-225. 
Gadsby, J.E., Heap, R.B. \& Burton, R.D. (1980) Oestrogen production by blastocyst and early embryonic tissue of various species. J. Reprod. Fert. 60, 409-417.

Garverick, H.A., Polge, C. \& Flint, A.P.F. (1982) Oestradiol administration raises luteal $\mathrm{LH}$ receptor levels in intact and hysterectomized pigs. J. Reprod. Fert. 66, 371-377.

Geisert, R.D., Biggers, B., Wettemann, R.P. \& Zavy, M.T. (1984) Length of pseudopregnancy in the gilt is influenced by days of oestradiol benzoate treatment. Proc. 10th Int. Congr. Anim. Reprod. \& A.I. Urbana I, 507, Abstr.

Ginther, O.J. (1983) Mobility of early equine conceptus. Theriogenology 19, 603-611.

Godkin, J.D., Bazer, F.W., Lewis, G.S., Geisert, R.D. \& Roberts, R.M. (1982) Synthesis and release of polypeptides by pig conceptuses during the period of blastocyst elongation and attachment. Biol. Reprod. 27, 977-987.

Godkin, J.D., Bazer, F.W., Moffatt, J., Sessions, F. \& Roberts, R.M. (1982) Purification and properties of a major, low molecular weight protein released by the trophoblast of sheep blastocysts on Day 13-21. J. Reprod. Fert. 65, 141-150.

Godkin, J.D., Bazer, F.W. \& Roberts, R.M. (1984a) Ovine trophoblast protein 1 , an early secreted blastocyst protein, binds specifically to uterine endometrium and affects protein synthesis. Endocrinology 114, 120-130.

Godkin, J.D., Bazer, F.W., Thatcher, W.W. \& Roberts, R.M. (1984b) Proteins released by cultured Day 15-16 conceptuses prolong luteal maintenance when introduced into the uterine lumen of cyclic ewes. $J$. Reprod. Fert. 71, 57-64.

Goff, A.K. \& Pontriand, D. (1985) Effect of pregnancy on the oxytocin stimulation of $\mathrm{PGF}_{2 a}$ in the mare. Biol. Reprod. 32 (Suppl. 1), 93, Abstr.

Guthrie, H.D. \& Rexroad, C.D. (1981) Endometrial prostaglandin $F$ release in vitro and plasma 13,14dihydro-15-keto prostaglandin $F_{2 a}$ in pigs with luteolysis blocked by pregnancy, oestradiol benzoate or human chorionic gonadotropin. J. Anim. Sci. 52, $330-337$.

Heyman, Y., Camous, S., Fevre, J., Meziou, W. \& Martal, J. (1984) Maintenance of the corpus luteum after uterine transfer of trophoblastic vesicles to cyclic cows and ewes. J. Reprod. Fert. 70, 533-540.

Hunter, R.H.F. (1964) Superovulation and fertility in the pig. Anim. Prod. 6, 189-194.

Kittok, R.J. \& Britt, J.H. (1977) Corpus luteum function in ewes given estradiol during the estrous cycle or early pregnancy. J. Anim. Sci. 45, 336-341.

Knickerbocker, J.J., Thatcher, W.W., Bazer, F.W., Drost, M., Barron, D.H., Fincher, K.B. \& Roberts, R.M. (1984) Proteins secreted by cultured day 17 conceptuses extend luteal function in cattle. Proc. 10th Int. Congr. Anim. Reprod. \& A.I., Urbana 1, 88, Abstr.

Kooistra, L.H. \& Ginther, O.J. (1976) Termination of pseudopregnancy by administration of prostaglandin $\mathrm{F}_{2 \mathrm{a}}$ and termination of early pregnancy by administration of prostaglandin $F_{2 a}$, colchicine or by removal of embryos in mares. Am. J. vet. Res. 37, 35-41.

Lafrance, M. \& Goff, A.K. (1985) An antiluteolytic action of the bovine embryo via the hormonal axis oxytocin-prostaglandin $\mathrm{F}_{2 \mathrm{a}}$. Biol. Reprod. 32 (Suppl.

1), 41, Abstr.

Lewis, G.S. \& Waterman, R.A. (1982) Arachidonic acid metabolism by porcine blastocysts and endometrium. Biol. Reprod. 26 (Suppl. 1), 64A, Abstr. 55.

Mapletoft, R.J., Del Campo, M.R. \& Ginther, O.J. (1975) Unilateral luteotropic effect of uterine venous effluent of a gravid uterine horn in sheep. Proc. Soc. exp. Biol. Med. 150, 129-135.

Martal, J., Lacroix, M., Loudes, C., Saunier, M. \& Wintenberger-Torres, S. (1979) Trophoblastin, an antiluteolytic protein present in early pregnancy in sheep. J. Reprod. Fert. 56, 63-73.

McCracken, J.A., Schramm, W. \& Okulicz, W.C. (1984) Hormone receptor control of pulsatile secretion of $\mathrm{PGF}_{2 \mathrm{a}}$ from the ovine uterus during luteolysis and its abrogation in early pregnancy. In Prostaglandins in Animal Reproduction II, pp. 31-56. Eds L. E. Edqvist \& H. Kindahl. Elsevier Science Publishers, Amsterdam.

McDowell, K.J., Sharp, D.C., Peck, L.S. \& Cheves, L.L. (1985) Effect of restricted conceptus mobility on maternal recognition of pregnancy in mares. Equine vet. J., Suppl. 3, 23-24.

Moor, R.M. \& Rowson, L.E.A. (1966a) Local uterine mechanisms affecting luteal function in the sheep. $J$. Reprod. Fert. 11, 307-310.

Moor, R.M. \& Rowson, L.E.A. (1966b) The corpus luteum of the sheep: effect of the removal of embryo on luteal function. J. Endocr. 34, 497-502.

Nishikawa, Y. (1959) Studies on Reproduction in Horses. Japan Racing Association, Tokyo.

Northey, D.L. \& French, L.R. (1980) Effect of embryo removal and intrauterine infusion of embryonic homogenates on the lifespan of the bovine corpus luteum. J. Anim. Sci. 50, 298-302.

Poyser, N.L. (1984) Prostaglandin production by the uterus of the nonpregnant and early pregnant guinea pig. Anim. Reprod. Sci. 7, 1-30.

Schlafke, S. \& Enders, A.C. (1975) Cellular basis of interaction between trophoblast and uterus at implantation. Biol. Reprod. 12, 41-65.

Sharp, D.C. \& McDowell, K.J. (1985) Critical events surrounding the maternal recognition of pregnancy in mares. Equine vet. J., Suppl. 3, 19-22.

Sharp, D.C., Zavy, M.T., Vernon, M.W., Bazer, F.W., Thatcher, W.W., Berglund, L.A. \& McDowell, K.J. (1984) The role of prostaglandins in the maternal recognition of pregnancy in mares. Anim. Reprod. Sci. 7, 269-282.

Shemesh, M., Milaguir, F., Ayalon, N. \& Hansel, W. (1979) Steroidogenesis and prostaglandin synthesis by cultured bovine blastocysts. J. Reprod. Fert. 56, 181-185.

Silvia, W.J., Ottobre, J.S. \& Inskeep, E.K. (1984) Concentrations of prostaglandins $\mathrm{E}_{2}, \mathrm{~F}_{2 \alpha}$ and 6-ketoprostaglandin $\mathrm{F}_{\mathrm{la}}$ in the utero-ovarian venous plasma of nonpregnant and early pregnant ewes. Biol. Reprod. 30, 936-944.

Stoner, C.S., Geisert, R.D., Bazer, F.W. \& Thatcher, W.W. (1981) Characterization of estrogen patterns in early pregnancy and cyclic gilts. J. Anim. Sci. 53 (Suppl. 1), 308, Abstr.

Terqui, M., Martinat-Botte, F. \& Thatcher, W.W. (1979) Early diagnosis of pregnancy in sows: Determination 
of $\mathrm{PGF}_{2 a}$ levels on the 14th and 15th days after insemination. Journées Rech. porcine en France 11, $365-371$.

Thatcher, W.W., Knickerbocker, J.J., Bartol, F.F., Bazer, F.W., Roberts, R.M. \& Drost, M. (1985) Maternal recognition of pregnancy in relation to the survival of transferred embryos: endocrine aspects. Theriogenology 23, 129-144.

Vallet, J.L., Bazer, F.W. \& Roberts, R.M. (1985a) The effect of ovine trophoblast protein-1 on protein and cAMP production by Day 12 endometrial explant cultures. Biol. Reprod. 32 (Suppl. 1), 64, Abstr.

Vallet, J.L., Bazer, F.W. \& Roberts, R.M. (1985b) Effect of ovine trophoblast protein-1 induced endometrial proteins on progesterone production by the corpus luteum and cAMP response of endometrial to oxytocin. J. Anim. Sci. 61, Suppl. 1, 377, Abstr. 413.

Wathes, D.C., Swann, R.W. \& Pickering, B.J. (1984) Variations in oxytocin, vasopressin and neurophysin concentrations in the bovine ovary during the oestrous cycle and pregnancy. J. Reprod. Fert. 71, 551-557.

Wilson, M.E., Lewis, G.S. \& Bazer, F.W. (1979) Proteins of ovine blastocyst origin. Biol. Reprod. 20 (Suppl. 1), 101A, Abstr.

Zarco, L., Stabenfeldt, C.H., Kindahl, H., Bradford, G.E. \& Basu, S. (1984) A detailed study of prostaglandin $F_{2 a}$ release during luteolysis and establishment of pregnancy in the ewe. Biol. Reprod. 30 (Suppl. 1), 153, Abstr.

Zavy, M.T., Mayer, R., Vernon, M.W., Bazer, F.W. \& Sharp, D.C. (1979) An investigation of the uterine luminal environment of nonpregnant and pregnant Pony mares. J. Reprod. Fert., Suppl. 27, 403-411.

Zavy, M.T., Vernon, M.W., Asquith, R.L., Bazer, F.W. \& Sharp, D.C. (1984) Effect of exogenous gonadal steroids and pregnancy on uterine luminal prostaglandin F in mares. Prostaglandins 27, 31 1-320. 